\title{
A comparison of two seabird communities on opposite coasts of the Alborán Sea (western Mediterranean)*
}

\author{
MARIANO PARACUELLOS ${ }^{1}$ and DIEGO JEREZ ${ }^{2}$ \\ ${ }^{1}$ Departmento de Flora y Fauna, Consejería de Medio Ambiente (Junta de Andalucía), C. Res. Oliveros, bl. Singular, \\ 04071, Almería, Spain. E-mail: mparacuellos@cajamar.es \\ ${ }^{2}$ Ctra. Alfonso XIII, 68, Urb. Chafarinas, 17, 52005, Melilla, Spain.
}

\begin{abstract}
SUMMARY: We compared the seabird communities at two sites of the southern and northern shores of the Alborán Sea in the Western Mediterranean (Melilla and Adra respectively) during a whole year. Similarities and differences in environmental characteristics of the two study sites were caused by a set of geographical, physical and socio-economic human factors. Sampling was performed weekly during two-hour periods by counting seabirds crossing a given point of the coast. We found similarities in the composition and seasonality of the species between Melilla and Adra. However, there were differences between the two sites in the number of species and individuals, which were usually higher on the southern shore. In this area, seabirds depending on marine trophic resources were more abundant, whereas on the northern shore the most abundant seabird species were those whose feeding habits were not so dependent on sea resources.
\end{abstract}

Key words: Alborán Sea, community, environmental features, western Mediterranean, seabirds.

RESUMEN: COMPARACIÓN DE DOS COMUNIDADES DE AVES MARINAS REPRODUCTORAS EN COSTAS OPUESTAS DEL MAR DE ALBORÁN (MEDITERRÁNEO OCCIDENTAL). - Se comparan las comunidades de aves marinas en dos localidades de las orillas norte y sur del mar de Alborán y en el Mediterráneo occidental (Melilla y Adra respectivamente) durante un ciclo anual. Las similitudes y diferencias en las características ambientales de ambos lugares se debieron a un conjunto de factores físicos, geográficos y socioeconómicos. El muestreo se realizó semanalmente durante periodos de dos horas y consistió en el conteo de las aves marinas que cruzaron un sector determinado de costa. Se hallaron similitudes en la composición y estacionalidad de las especies entre Melilla y Adra. Sin embargo se observaron diferencias entre ambos sitios en relación al número de especies e individuos, normalmente mayores en la orilla sur. En esta zona fueron más abundantes las aves marinas más dependientes de los recursos tróficos marinos mientras que las especies más abundantes en la orilla norte fueron aquellas cuyos hábitos tróficos no son tan dependientes de los recursos marinos.

Palabras clave: mar de Alborán, comunidad, características ambientales, Mediterráneo occidental, aves marinas.

\section{INTRODUCTION}

Seabird communities are influenced, at different spatial and temporal scales, by dynamic ecological processes which affect the availability, distribution and abundance of their prey, as well as their nesting and resting places (Hunt and Schneider, 1987; Aindley et al., 1994; Monteiro et al., 1996). The study

\footnotetext{
*Received July 5, 2001. Accepted July 27, 2002.
}

and quantification of these ecological processes has been widely covered in the investigation of diverse marine zones of the world (Berruti et al., 1989; Anker-Nilssen and Barrett, 1991; Elphick and Hunt, 1993; Blaber and Milton, 1994; Tasker and Reid, 1997; Abelló and Oro, 1998).

Due to its strategic geographical position between the Atlantic and Mediterranean environments, and its socio-economic situation between the European continent and the North African region, 
the Alborán Sea is a meeting point that has been used by man since the beginning of the Western civilization. There have been continuous major human interventions, mainly throughout the $20^{\text {th }}$ century, which, along with other natural processes, have led to the ecological imbalances found today (Rodríguez, 1982; García, 1985; Mas, 1995). It is because of these ecological differences between its various coastal zones that this sea constitutes an ideal study site for assessing the human effect on bird communities. Nevertheless, up to now most authors who have studied seabird communities in the Alborán Sea have analysed exclusively the composition of only one of its coasts, either the southern coast (Jacob and Courbet, 1980; Berthon and Berthon, 1984) or the northern coast (Carrera, 1988; Paterson, 1997). Although some studies deal with distribution aspects of seabirds on both coasts (de Juana and Paterson, 1986; Paterson, 1990; Hashmi, 2000), none of them analyse the ecological differences between their communities.

Due to the lack of such an analysis, we aim to compare the characteristics of the seabird communities at two sites of the southern and northern coasts of the Alborán Sea, Melilla and Adra, during a whole annual cycle. Their differences and affinities will be discussed in relation to the ecological differences of these two areas. Since seabirds are considered as bioindicators of environmental parameters (Monaghan, 1996; Furness and Camphuysen, 1997), studies like this can provide useful information for detecting ecological discontinuities in the coastal environment.

\section{STUDY AREA AND METHODS}

The Alborán Sea located at the western end of the Mediterranean Sea (Fig. 1). Within this region there are upwellings off some zones of the Iberian coast, though they are usually absent in the waters of the North African coasts (Rodríguez, 1982; García, 1985). The study sites were the shores of Melilla and Adra (hereafter, $M$ for the North African coast, $35^{\circ} 21^{\prime} \mathrm{N}, 2^{\circ} 59^{\prime} \mathrm{W}$ and A for the Iberian coast, $\left.36^{\circ} 44^{\prime} \mathrm{N}, 3^{\circ} 3^{\prime} \mathrm{W}\right), 160 \mathrm{~km}$ apart (Fig. 1). The littoral stretches of $\mathrm{M}$ and $\mathrm{A}$ were located respectively on the eastern side of Tres Forcas Cape, Morocco, and the mountains of Contraviesa, Spain. Both coasts have a mountainous relief, broken by small sandy beaches with coastal wetlands or islands in the vicinities, used by seabirds as resting, breeding or feeding places (de

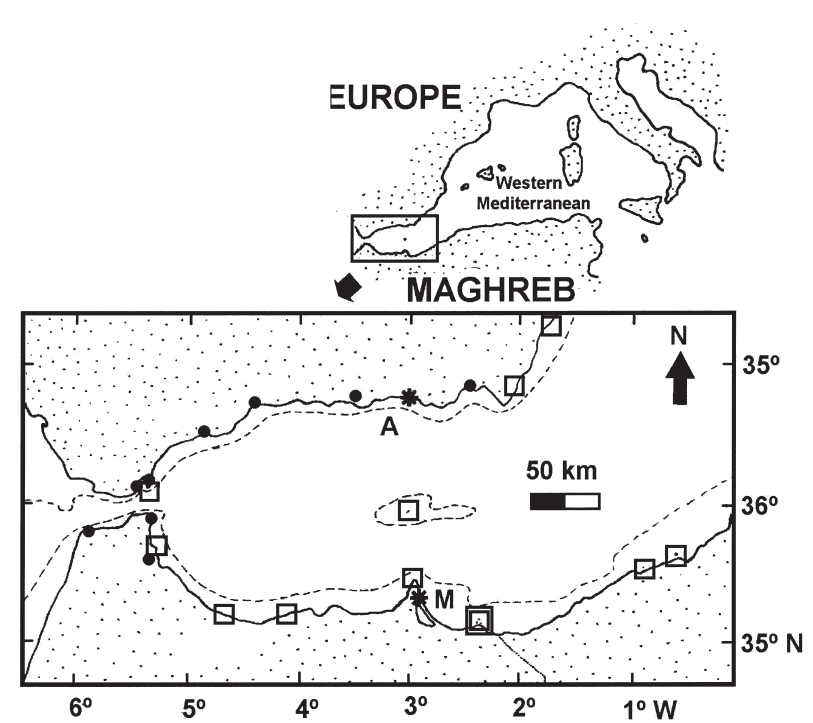

FIG. 1. - Geographical situation of the area and the two study sites (asterisks). Also marked, the $200 \mathrm{~m}$ isobath (with broken lines), the main urban nuclei of the littoral (black circles), and the breeding colonies for the most common species at Melilla or Adra (see text), with more than 100 and 1,000 pairs (squares and double squares respectively; according to Jacob and Courbet, 1980; Berthon and Berthon, 1984; de Juana, 1984; Aguilar et al., 1993; Paracuellos and Nevado, 1995; Thibault et al., 1996; own data).

Juana et al., 1984; Paracuellos et al., 1994; Charco et al., 1995; Paracuellos and Nevado, 1995). The continental shelf of the southern coast is approximately twice the width of the shelf of the northern coast (20 $\mathrm{km}$ vs. $12 \mathrm{~km}$ maximum width respectively, Fig. 1). Despite the relative proximity of the two study sites, the existence of a high economic imbalance in the human aspect is great. Around M people have a generally depressed economy, in the process of development, whereas around A local people have larger incomes linked with a higher development than around of M. Hence, alteration and disturbance on the littotal, marine pollution and overfishing are more intensive on the northern coast (Rodríguez, 1982; García, 1985; Lara, 1987; Oliver, 1991; Difusora Internacional, 1993-1996; Mas, 1995; Instituto de Estadística de Andalucía, 1997).

A weekly census of seabirds at each site was made during an annual cycle, from 6 September 1997 to 30 August 1998, although during the third week of January and the fourth week of August no counts were made at A. The census was carried out on the same day at $\mathrm{M}$ and $\mathrm{A}$ in $50 \%$ of the cases, whereas the delay between counts in both zones was 1 to 2 days for the other $50 \%$. Counts were performed at midday (11:00-16:00 GMT in the winter and 10:00-15:00 GMT in the summer) because of the lower frequency of fishing vessels entering or leaving the nearby ports during that time, which 
TABLE 1. - Monthly average values of the temporal index of abundance ( $\mathrm{n}^{\circ}$ individuals/hour) for each species of seabird at Melilla and Adra. The ecological category of each species is indicated. (+), birds essentially dependent on trophic resources existing in the sea; (o), birds which usually use alternative trophic resources of a non-marine origin; $\mathrm{N}$, sample size.

\begin{tabular}{|c|c|c|c|c|c|c|c|c|c|c|c|c|c|}
\hline & & SEP & OCT & NOV & DEC & JAN & FEB & MAR & APR & MAY & JUN & JUL & AUG \\
\hline \multicolumn{14}{|l|}{ Melilla } \\
\hline Gavia arctica & + & 一 & - & $\overline{a r}$ & - & 0.1 & - & 一 & -- & - & - & - & - \\
\hline Podiceps cristatus & o & - & 6.1 & 2.6 & 0.4 & 0.6 & - & - & - & -- & - & - & - \\
\hline Calonectris diomedea & + & 96.0 & 547.1 & 773.2 & - & - & 23.0 & 829.9 & 945.5 & 409.9 & 346.3 & 35.1 & 13.3 \\
\hline Puffinus sp. & + & - & 21.1 & 101.7 & 24.1 & 4.2 & - & - & - & - & - & 0.5 & 1.1 \\
\hline Hydrobates pelagicus & + & - & 0.1 & 0.1 & 0.1 & 0.2 & 0.1 & - & -- & - & - & - & - \\
\hline Morus bassanus & + & 0.3 & 3.8 & 19.7 & 47.1 & 38.7 & 41.9 & 3.0 & 3.4 & 0.4 & 0.1 & - & - \\
\hline Phalacrocorax carbo & o & - & 0.1 & 5.0 & 2.6 & 1.0 & 2.4 & 1.4 & 0.1 & - & - & - & - \\
\hline Ph. aristotelis & + & - & - & - & - & 0.2 & 0.4 & 0.8 & 0.3 & - & - & - & - \\
\hline Melanitta nigra & + & - & -- & - & 0.8 & 0.3 & - & - & - & -- & -- & -- & -- \\
\hline Mergus serrator & o & - & 0.1 & 0.3 & - & 0.4 & 0.4 & - & - & - & - & - & - \\
\hline Pandion haliaetus & o & - & 0.1 & 0.3 & - & 0.2 & 0.1 & 0.1 & 0.1 & - & - & - & - \\
\hline Stercorarius parasiticus & + & - & - & 0.1 & 0.4 & 0.1 & - & 0.1 & - & - & - & - & - \\
\hline Catharacta skua & + & - & 0.1 & 0.3 & 0.8 & - & 0.3 & 1.3 & 2.3 & 1.0 & 一 & - & 0.1 \\
\hline Larus melanocephalus & o & - & - & 0.1 & 0.6 & 0.7 & 0.6 & - & - & - & - & -- & - \\
\hline L. minutus & o & - & - & -- & 0.6 & 0.2 & -- & - & - & - & - & - & - \\
\hline L. ridibundus & o & 9.4 & 8.3 & 37.3 & 109.9 & 90.2 & 45.4 & 9.3 & - & - & - & 0.3 & 0.8 \\
\hline L. genei & o & - & 0.4 & 0.5 & 0.9 & 1.2 & 1.6 & 0.8 & 0.5 & - & —- & - & - \\
\hline L. audouinii & + & 19.5 & 2.9 & 11.8 & 14.8 & 28.2 & 26.0 & 89.0 & 88.6 & 63.6 & 113.1 & 38.0 & 14.2 \\
\hline L. fuscus & o & 2.4 & 2.8 & 1.2 & 5.0 & 5.5 & 3.0 & 0.6 & - & - & -- & - & -- \\
\hline L. cachinnans & o & 134.6 & 126.9 & 146.5 & 244.3 & 182.1 & 84.9 & 88.3 & 101.4 & 54.9 & 104.8 & 40.1 & 25.0 \\
\hline Rissa trydactyla & + & - & - & - & - & 3.4 & 0.3 & - & - & - & - & - & - \\
\hline Gelochelidon nilotica & o & - & - & - & - & - & - & 0.5 & 4.5 & 0.1 & 一 & - & - \\
\hline Sterna caspia & o & - & 0.3 & 0.4 & 0.1 & - & 0.1 & 0.3 & - & - & - & - & - \\
\hline S. maxima & o & - & - & - & 0.1 & 0.2 & - & - & -- & - & - & - & - \\
\hline S. bengalensis & + & 5.3 & 14.8 & 0.6 & 0.6 & 0.2 & -- & 0.8 & 1.5 & 1.6 & 0.1 & 0.3 & 0.4 \\
\hline S. sandvicensis & + & 20.6 & 16.6 & 23.0 & 19.6 & 4.4 & 1.0 & 1.1 & 3.1 & 3.2 & 1.3 & - & 0.5 \\
\hline S. hirundo & o & - & -- & 0.6 & - & - & - & - & - & - & - & - & - \\
\hline S. albifrons & o & - & - & - & - & - & - & - & - & 6.6 & 0.5 & 0.4 & 0.3 \\
\hline Chlidonias niger & o & 0.1 & 0.4 & 0.7 & - & - & - & - & 1.1 & 2.7 & - & - & 1.2 \\
\hline Alca torda & + & - & - & 1.3 & 3.5 & 0.7 & 0.5 & - & - & 0.1 & - & - & - \\
\hline Fratercula artica & + & 一 & 一 & - & 0.4 & 0.6 & - & 一 & 一 & - & - & - & 一- \\
\hline $\mathrm{N}$ & & 4 & 4 & 5 & 4 & 5 & 4 & 4 & 4 & 5 & 4 & 4 & 5 \\
\hline \multicolumn{14}{|l|}{ Adra } \\
\hline Podiceps nigricollis & o & - & - & - & 一 & - & 0.1 & 0.3 & - & - & - & - & - \\
\hline Calonectris diomedea & & 0.3 & 24.1 & 0.2 & - & - & - & 0.3 & 0.4 & 1.8 & 7.9 & 0.8 & 3.0 \\
\hline Puffinus sp. & & 0.8 & 35.6 & 27.8 & 40.1 & 9.9 & 0.9 & 0.8 & 0.1 & 0.4 & 5.5 & - & - \\
\hline Hydrobates pelagicus & & - & 0.1 & - & - & - & - & - & - & - & - & -- & - \\
\hline Morus bassanus & & 2.1 & 23.6 & 34.4 & 16.4 & 13.5 & 5.9 & 1.1 & 0.9 & 1.3 & 2.5 & - & 0.3 \\
\hline Phalacrocorax carbo & & - & - & 0.7 & 0.3 & 0.5 & 0.6 & 0.5 & - & - & - & - & - \\
\hline Stercorarius pomarinus & + & - & - & 0.1 & - & - & - & - & - & - & - & - & - \\
\hline S. parasiticus & & - & 0.1 & - & - & - & - & - & - & - & - & - & 0.1 \\
\hline Catharacta skua & & - & - & 0.3 & - & - & 1.1 & 0.1 & 0.1 & 0.1 & 0.1 & - & - \\
\hline Larus melanocephalus & & - & 0.1 & 0.2 & 0.5 & 0.8 & 1.8 & - & - & - & - & 0.3 & - \\
\hline L. minutus & & - & - & - & - & - & - & 0.1 & - & 0.1 & - & - & 一- \\
\hline L. sabini & + & - & - & - & - & - & 0.3 & - & - & - & - & - & - \\
\hline L. ridibundus & & 4.6 & 15.6 & 46.4 & 64.0 & 25.5 & 26.1 & 4.6 & 0.8 & 1.7 & 0.4 & 5.4 & 5.0 \\
\hline L. audouinii & & 2.9 & 2.3 & 3.4 & 0.1 & 0.5 & 7.9 & 1.9 & 2.8 & 6.7 & 11.4 & 1.8 & 3.5 \\
\hline L. fuscus & & 15.6 & 46.0 & 133.2 & 134.5 & 151.4 & 112.8 & 71.4 & 35.3 & 2.7 & - & - & 5.3 \\
\hline L. cachinnans & & 40.3 & 46.9 & 6.0 & 4.4 & 4.5 & 6.1 & 10.0 & 20.8 & 65.0 & 12.1 & 25.3 & 57.9 \\
\hline Rissa trydactyla & & - & - & 0.7 & - & 0.1 & 0.6 & - & - & - & - & - & - \\
\hline Gelochelidon nilotica & & - & - & - & - & - & - & - & - & 0.1 & - & 0.1 & - \\
\hline Sterna sandvicensis & & 3.6 & 13.4 & 5.9 & 1.6 & 4.1 & 6.8 & 7.8 & 2.5 & - & - & - & 0.5 \\
\hline S. hirundo & & 0.1 & 0.1 & - & - & - & - & - & - & 0.4 & -- & 0.6 & 0.1 \\
\hline S. albifrons & & - & - & - & - & - & -- & -- & - & - & - & - & 0.3 \\
\hline Chlidonias niger & & 一 & 一- & - & - & - & - & - & -- & - & - & - & 0.3 \\
\hline Alca torda & & - & - & 1.0 & 8.5 & 2.4 & 2.9 & 1.6 & 一- & -- & - & - & - \\
\hline $\mathrm{N}$ & & 4 & 4 & 5 & 4 & 4 & 4 & 4 & 4 & 5 & 4 & 4 & 4 \\
\hline
\end{tabular}

could possibly distort the results because of the usual association of flocks of seabirds with fishing vessels (Oro and Ruiz, 1997). In each census, which was always made from the same point on both shores, all seabirds in flight or settled on the sea were counted during two hours, trying to avoid duplication. Overall, 104 hours were spent at M, and 100 hours at A. Similar optics (60x magnifying 
power) and census positions (elevated points at 15$25 \mathrm{~m}$ a.s.l., not more than $15 \mathrm{~m}$ from the tide line and with an angle of marine visibility of about $180^{\circ}$ ) were used in both cases. With these counting characteristics, the visual range for identification of the species reached a maximum distance of $2,500 \mathrm{~m}$. Similar counting methods have been used by other authors (Paterson, 1990; van Franeker, 1994).

The total number of species and the specific index of abundance were considered. The values of the index of abundance of the most frequent species (with an average value of $>1$ individual/hour in whatever locality or season), as well as of guilds of species, were also analysed. Guilds were defined attending to the trophic resources existing in the sea (e.g. fish, shellfish, mollusks, marine algae, nonmarine resources) (Table 1; Snow and Perrins, 1998). Puffinus shearwaters (either Mediterranean shearwater P. yelkouan or Balearic shearwater $P$. mauretanicus) (Snow and Perrins, 1998; Hashmi, 2000), were included as "small shearwaters" (Puffinus sp.) because of the difficulty of identifying them correctly.

A dissimilarity cluster analysis was used for each locality, based on the Complete Linkage algorithm (Jobson, 1992). This was based on the results of a matrix obtained by comparing the specific similarity through the pairing of all the months of the year using the Czchanovsky index (Margalef, 1974). Taking into account the non-normality of data, the Spearman correlation coefficient was used to test associations, the Mann-Whitney U-test for the contrast of averages and the G-test for the contrast of frequencies (Siegel and Castellan, 1988; Sokal and Rohlf, 1994). Data in the text and in the Table 2 are expressed as mean values $\pm \mathrm{SD}$.

\section{RESULTS}

During the study period we observed 57,914 individuals of 31 species at $\mathrm{M}$ and 13,410 individuals of 23 at A. Most birds were non-resident and were observed $<9$ months at each site. The average permanence time was similar for both shores of the Alborán Sea $(5.4 \pm 3.4$ and $5.6 \pm 4.1$ months for $M$ and $\mathrm{A}$ respectively; $\mathrm{Z}=0.2, \mathrm{P}=0.8$; Table 1 ).

Two distinct season intervals were identified at each site, regarding the similarity of species in each month of the year (Fig. 2). One of the periods included the months from November to March (hereafter the winter period), and the other included

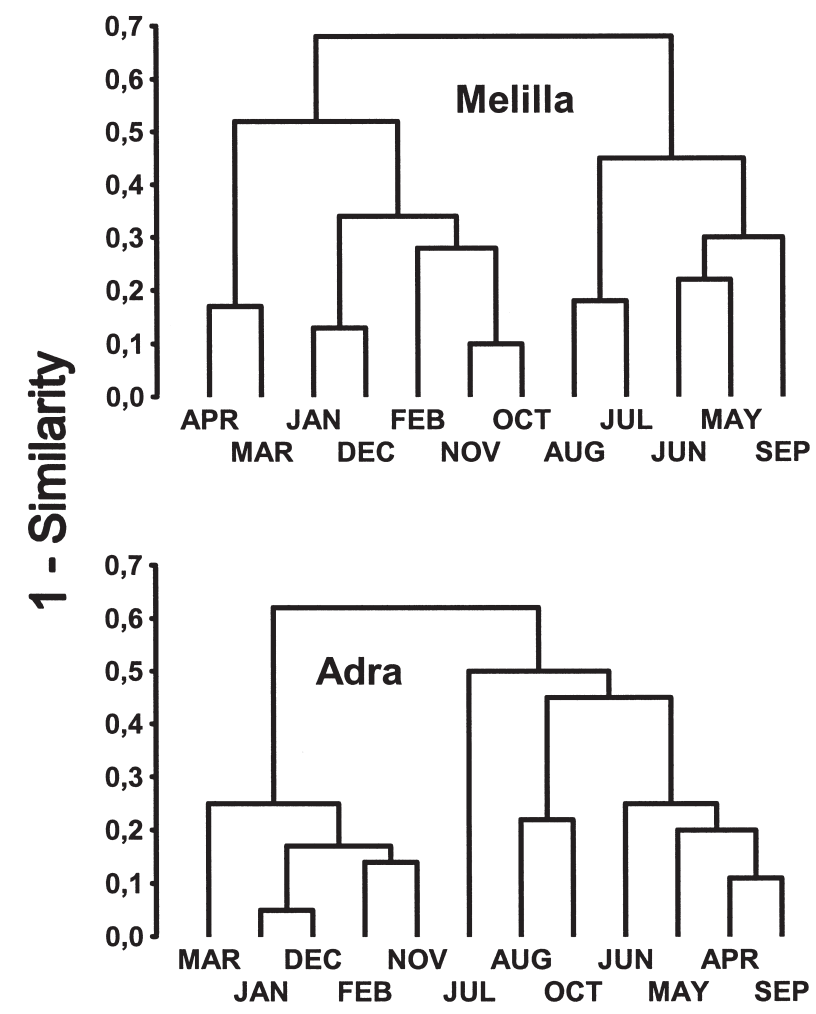

FIG. 2. - Cluster analysis taking into account the dissimilarity coefficient (1 - specific inter-monthly similarity) in Melilla and in Adra.

the months from May to September (hereafter the summer period). In A both April and October were grouped with the summer months, though in $M$ they were not.

Though species composition was very similar between $\mathrm{A}$ and $\mathrm{M}$, some differences were found between the two groups. A number of species on the southern coast were not seen on the northern coast (11 exclusive to $\mathrm{M}$ against 3 to A; Table 1), some of them mainly distributed in north and west Africa in the western Paleartic, like the royal tern Sterna maxi$m a$ and the lesser crested tern Sterna bengalensis (de Juana and Paterson, 1986; Snow and Perrins, 1998; Hashmi, 2000). Only 12 species were frequently recorded (Table 2). Of these, the most abundant ones were Cory's shearwater Calonectris diomedea (mainly during their migrations) and the yellowlegged gull Larus cachinnans (all year at $\mathrm{M}$ and only in summer at A), as well as the lesser blackbacked gull Larus fuscus (during the winter) (Tables 1 and 2).

While a positive and significant relationship was found between the specific richness of both coasts throughout the year, there was no relationship regarding overall abundance (Table 2). Taking into account only the most frequent species, we found 
TABLE 2. - Seasonal average values of richness ( $n^{\circ}$ of species/census) and of the temporal index of abundance ( $n^{\circ}$ individuals/hour) for the communities of Melilla and Adra, as well as of the temporal index of abundance ( $\mathrm{n}^{\circ}$ individuals/hour) for each of the most frequent species of seabirds separately. The statistical differences between the average seasonal values of Melilla and Adra (Z) are also expressed, as well as the relationships between their annual values of richness and abundance $(\mathrm{R})$. Levels of significance: $* * *, \mathrm{P}<0.001 ; * *, \mathrm{P}<0.01 ; *, \mathrm{P}<0.05$; n.s.- not significant. $\mathrm{N}$ - sample size.

\begin{tabular}{|c|c|c|c|c|c|c|c|}
\hline & Melilla & $\begin{array}{c}\text { Winter period } \\
\text { Adra }\end{array}$ & $\mathrm{Z}$ & Melilla & $\begin{array}{l}\text { ammer period } \\
\text { Adra }\end{array}$ & $\mathrm{Z}$ & $\mathrm{R}$ \\
\hline Richness & $12.9 \pm 2.6$ & $8.8 \pm 1.7$ & $4.6 * * *$ & $6.2 \pm 2.1$ & $5.6 \pm 1.6$ & 0.9 n.s. & $0.7 * * *$ \\
\hline Abundance & $654.9 \pm 653.5$ & $206.3 \pm 111.5$ & $4.2 * * *$ & $312.7 \pm 249.2$ & $61.1 \pm 47.0$ & $4.1 * * *$ & 0.0 n.s. \\
\hline Calonectris diomedea & $330.8 \pm 649.3$ & $0.1 \pm 0.2$ & $2.3 *$ & $183.0 \pm 202.5$ & $2.7 \pm 3.1$ & $5.0 * * *$ & $0.4 * *$ \\
\hline Puffinus sp. & $28.4 \pm 57.7$ & $16.4 \pm 24.1$ & 0.6 n.s. & $0.3 \pm 0.6$ & $1.3 \pm 4.5$ & 0.1 n.s. & $0.6 * * *$ \\
\hline Morus bassanus & $30.0 \pm 20.4$ & $15.2 \pm 17.6$ & $2.5 *$ & $0.2 \pm 0.3$ & $1.2 \pm 1.8$ & $2.1 *$ & $0.7 * * *$ \\
\hline Phalacrocorax carbo & $2.5 \pm 2.5$ & $0.5 \pm 0.5$ & $3.1 * *$ & - & - & 0.0 n.s. & $0.6 * * *$ \\
\hline Larus ridibundus & $58.9 \pm 50.4$ & $33.9 \pm 29.2$ & 1.7 n.s. & $1.9 \pm 5.1$ & $3.3 \pm 4.1$ & 1.8 n.s. & $0.8 * * *$ \\
\hline L. audouinii & $32.7 \pm 29.5$ & $2.8 \pm 6.2$ & $5.0 * * *$ & $48.7 \pm 41.7$ & $5.3 \pm 8.1$ & $5.1 * * *$ & 0.2 n.s. \\
\hline L. fuscus & $3.1 \pm 2.6$ & $121.2 \pm 63.3$ & $5.6 * * *$ & $0.4 \pm 1.3$ & $4.6 \pm 7.1$ & $2.3 *$ & $0.7 * * *$ \\
\hline L. cachinnans & $150.6 \pm 70.2$ & $6.2 \pm 4.4$ & $5.6 * * *$ & $69.0 \pm 45.3$ & $41.3 \pm 43.0$ & $2.4 *$ & $-0.5 * * *$ \\
\hline Sterna bengalensis & $0.4 \pm 0.6$ & - & $2.0 *$ & $1.5 \pm 3.0$ & - & $2.5 *$ & 0.0 n.s. \\
\hline S. sandvicensis & $10.2 \pm 10.9$ & $5.3 \pm 3.9$ & 0.3 n.s. & $4.8 \pm 11.1$ & $0.8 \pm 2.3$ & $2.6 * *$ & $0.4 *$ \\
\hline S. albifrons & - & - & 0.0 n.s. & $1.7 \pm 3.2$ & $0.0 \pm 0.1$ & 1.9 n.s. & 0.1 n.s. \\
\hline Alca torda & $1.2 \pm 1.8$ & $3.2 \pm 4.3$ & 1.9 n.s. & $0.0 \pm 0.1$ & - & 0.2 n.s. & $0.4 * *$ \\
\hline $\mathrm{N}$ & 22 & 21 & & 22 & 21 & & 50 \\
\hline
\end{tabular}

that similar variations existed during the year between both coasts except for the yellow-legged gull, Audouin's gull Larus audouinii, the lesser crested tern and the little tern Sterna albifrons (Table 2). Larger values were obtained for the average species richness of seabirds at $\mathrm{M}$ during the winter period and also larger general abundance values during the whole year (Table 2).

As shown in Figure 3, when birds were grouped according to ecological affinity, no similarity between the two shores was observed taking into account the proportional contribution of each group to the total abundance of the community $\left(\mathrm{G}_{1}=136.0, \mathrm{P}<0.001\right.$ and $\mathrm{G}_{1}=72.9, \mathrm{P}<0.001$, for the winter and summer times respectively), owing to a predominance of seabirds essentially linked to the sea when foraging at M (always $50-75 \%$ of the total community abundance) and of those which usually preyed upon alternative trophic resources at A (in both seasons $>75 \%$ of the total community abundance).

\section{DISCUSSION}

The similar species composition and monthly fluctuations observed in the seabird communities on the southern and northern shores of the Alborán Sea (for other zones on both margins of the Alborán Sea see also de Juana and Paterson, 1986; Paterson, 1990; Hashmi, 2000) are probably related to the relative proximity of the study sites (Hunt and Schneider, 1987).

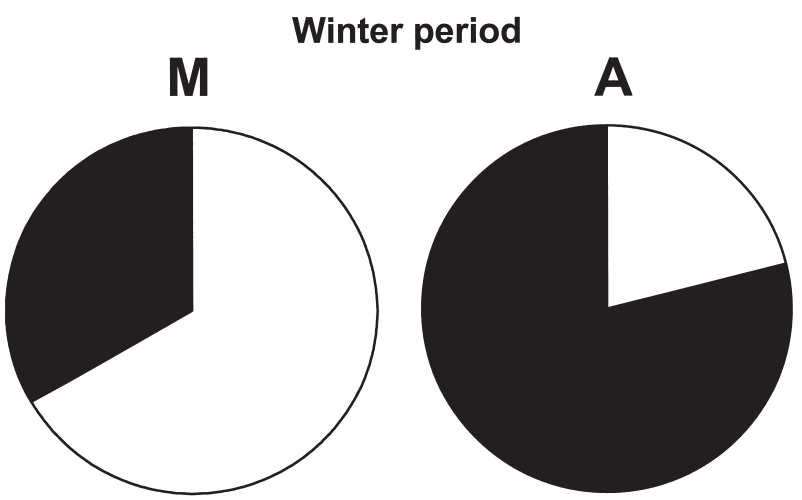

Summer period
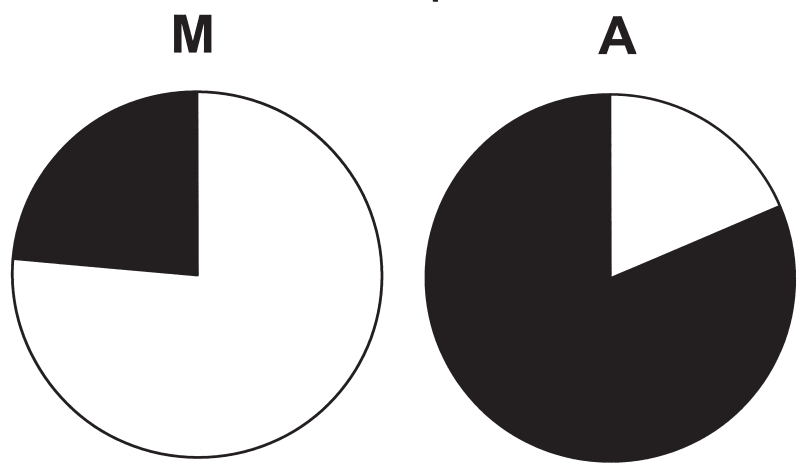

FIG. 3. - Proportional average contribution of the species of each group of ecological affinity to the total abundance of seabirds in winter (Winter period) and in summer (Summer period) periods for Melilla (M) and Adra (A). Within the white area, birds essentially dependent on marine trophic resources; within the black area, birds which usually use alternative trophic resources of a non-marine origin.

Despite the relative similarity in the structure of both communities, differences found in richness, total abundance and abundance of most frequent 
species when analysed separately for summer and winter cannot be explained in terms of distance between sites. The larger numbers on the south coast contrasted with the presence of the upwelling phenomenon exclusively in the north, which normally causes greater food availability for seabirds (Hunt and Schneider, 1987; Gil, 1992; Davenport, 1995).

As previously reported (Blaber and Milton, 1994; Garthe, 1997), the abundance of seabirds during the breeding period is directly related to the distance to the nearest breeding colonies. Hence, differences in abundance for Cory's shearwater, Audouin's gull and yellow-legged gulls between M and A were probably caused by the proximity of important breeding sites of these species at the southern study site. Colonies are mainly on the Chafarinas Islands, approximately $50 \mathrm{~km}$ east of $\mathrm{M}$ and $180 \mathrm{~km}$ south of A (Fig. 1; Aguilar et al., 1993). The existence of large colonies of seabirds at Chafarinas is probably related to both terrestrial and marine factors. The same factors might also explain the larger winter abundance of the northern gannet Morus bassanus, the great cormorant Phalacrocorax carbo and the sandwich tern Sterna sandvicensis, all nonbreeders in the Alborán Sea (Snow and Perrins, 1998). A larger continental shelf in the marine area off $\mathrm{M}$ (Fig. 1) probably determines a higher prey availability in that area (Hunt and Schneider, 1987). Moreover, the relative proximity of the Sebkha BouAreg at $\mathrm{M}$, one of the Maghreb wetlands with a greater abundance of great cormorant and sandwich tern during winter (Charco et al., 1995), probably influenced the higher numbers found for these species in the southern area.

The different results on abundance of seabirds between the Spanish and Moroccan sites were also probably influenced by a human factor. The greater economic development on the north side has brought a much higher disturbance to the environment (Rodríguez, 1982). The main causes of ecological deterioration that most probably affected seabirds are the following:

- While around A the coast is now very altered because of intensive human action (e.g. high levels of transformation of the landscape, density of autochthonous population and tourism), near $\mathrm{M}$ there are large tracts of shore with a much lower human presence (Fig. 1; Lara, 1987; Difusora Internacional, 1993, 1996; Sultana, 1993; Instituto de Estadística de Andalucía, 1997).

- Higher levels of marine pollution have been detected off the northern coasts (Mas, 1995). Pollu- tion has a negative effect on prey consumed by seabirds and hence an indirect effect on seabirds (Monteiro et al., 1996; Thibault et al., 1996; Furness and Camphuysen, 1997).

- The heavy fishery exploitation near the Iberian coasts of the Alborán Sea by the Spanish fishing fleet, with one of the greatest fishery productions in the world, has caused overfishing (Camiñas and Martorell, 1991; Oliver, 1991; F.J. Rubio, Consejería de Agricultura y Pesca, Junta de Andalucía, pers. comm.). For Morocco, its lower economic development has not allowed a similar exploitation of marine resources. However, the presence of trawling or purse-seine vessels fishing near $\mathrm{M}$ is much higher than that near A (own data) because $\mathrm{M}$ is a good fishing ground. A higher level of exploitation of marine resources as well as a higher productivity near M probably leads to a higher food availability for seabirds along the southern coast (de Juana, 1984; Anker-Nilssen and Barrett, 1991; Blaber and Milton, 1994; Garthe, 1997; Oro and Ruiz, 1997).

Differences in the quantitative composition of the seabird communities in the two study areas may have been caused mainly by the asymmetrical availability of food on each side (Witt et al., 1981; González-Solís et al., 1997; Furness and Camphuysen, 1997). Important populations of seabird species essentially linked to the sea when foraging still exist on the southern coast. A decrease of these species on the northern side is likely to have occurred paralleling environmental deterioration.

\section{ACKNOWLEDGEMENTS}

R. Ramírez collaborated during field data collection in Melilla. D. Oro, A. Paterson and an anonymous referee did a critical review of the original manuscript. We also thank J. Soler, J.G. Martínez and F.J. Rubio for their help. P.W. Kramer, A. Paterson and D. Oro helped to translate the original Spanish text.

\section{REFERENCES}

Abelló, P. and D. Oro. - 1998. Offshore distribution of seabirds in the Northwestern Mediterranean in June 1995. Colonial Waterbirds, 21: 422-426.

Aguilar, J.S., X. Monbailliu and A.M. Paterson (eds.) - 1993. Estatus y Conservación de Aves Marinas. SEO/BirdLife, Madrid.

Aindley, D.G., C.A. Ribic and W.R. Fraser. - 1994. Ecological structure among migrant and resident seabirds of the ScotiaWeddell Confluence region. J. Anim. Ecol., 63: 347-364.

Anker-Nilssen, T. and R.T. Barret. - 1991. Status of seabirds in 
northern Norway. Brit. Birds, 84: 329-341.

Berruti, A., N.J. Adams and S. Jackson. - 1989. The Benguela ecosystem. Part VI. Seabirds. Oceanogr. Mar. Biol. Ann. Rev. 27: 273-335.

Berthon, D. and S. Berthon. - 1984. Compte rendu de l'expédition Balbuzard sur les côtes méditerranéennes du Maroc. L'Oiseau et R. F. O., 54: 201-213.

Blaber, S.J.M. and D.A. Milton. - 1994. Distribution of seabirds at sea in the Gulf of Carpentaria, Australia. Aust. J. Mar. Fresh water Res., 45: 445-454.

Camiñas, J.A. and J.M. Martorell. - 1991. Informe de la mesa de trabajo sobre la problemática de la explotación pesquera de góbidos y afines en el litoral mediterráneo español. Inform. Téc. Inst. Esp. Oceanogr., 98: 2-61.

Carrera, E. - 1988. Invernada de gaviotas y charranes en la Península Ibérica. In: J.L. Tellería (ed.), Invernada de aves en la Península Ibérica, pp. 79-95. SEO, Madrid.

Charco, J., D. Jerez and J.M. Cabo. - 1995. Structure qualitative, quantitative, trophique et phenológique de la communaute d'oiseaux d'eau de la Sebkha Bou-Areg. Porphyrio, 7: 5-80.

Davenport, J. - 1995. Upwelling-generated plankton stadlines: important predictable food sources for seabirds at Husvik, South Georgia. Mar. Biol., 123: 207-217.

de Juana, E. - 1984. The status and conservation of seabirds in the Spanish Mediterranean. ICBP Technical Publication, 2: 347-361.

de Juana, E. and A.M. Paterson. - 1986. The status of the seabirds of the extreme Western Mediterranean. In: Medmaravis and X. Monbaillou (eds.), Mediterranean marine avifauna. Population studies and conservation, 39-106. Springer Verlag, Berlin.

de Juana, E., J. Varela and H.-H. Witt. - 1984. The conservation of seabirds at the Chafarinas Islands. ICBP Technical Publication, 2: $363-370$.

Difusora Internacional. - 1993-1996. Anuario Estadístico Universal: 1992, 1996 (2 vols.). Instituto Geográfico De Agostini, Barcelona.

Elphick, C.S. and G.L. Hunt Jr. - 1993. Variations in the distributions of marine birds with water mass in the Northern Bering Sea. The Condor, 95: 33-44.

Furness, R.W. and C.J. Camphuysen. - 1997. Seabirds as monitors of the marine environment. ICES J. Mar. Sci., 54: 726-737.

García, A.M. - 1985. Aspectos geográficos del Mar de Alborán: físicos, económicos y geoestratégicos. Paralelo 37º, 8/9: 267-298.

Garthe, S. - 1997. Influence of hydrography, fishing activity, and colony location on summer seabird distribution in the southeastern North Sea. ICES J. Mar. Sci., 54: 566-577.

Gil, J. - 1992. Consideraciones sobre el hábitat medioambiental de los cardúmenes de sardina en la plataforma continental mediterránea española y Golfo de León. Inform. Téc. Inst. Esp. Oceanogr., 114: 2-73.

González-Solís, J., D. Oro, L. Jover, X. Ruiz and V. Pedrocchi. 1997. Trophic niche and overlap of two sympatric gulls in the Southwestern Mediterranean. Oecologia, 112: 75-80.

Hashmi, D. - 2000. Opportunities for monitoring seabirds and cetaceans in the Strait of Gibraltar. In: P. Yésou and J. Sultana (eds.), Monitoring and conservation of birds, mammals and sea turtles of the Mediterranean and Black seas, 176-191. Environment Protection Department, Malta.

Hunt Jr., G.L. and D.C. Schneider - 1987. Scale-dependent processes in the physical and biological environment of marine birds. In: J.P. Croxall (ed.), Seabirds: Feeding biology and role in marine ecosystems, pp. 7-41. Cambridge University Press, Cambridge.

Instituto de Estadística de Andalucía. - 1997. Anuario Estadístico de Andalucía: 1997. Junta de Andalucía, Sevilla.

Jacob, J.P. and B. Courbet. - 1980. Oiseaux de mer nicheurs sur la côte algerienne. Le Gerfaut, 70: 385-401.

Jobson, J.D. - 1992. Applied Multivariate Data Analysis. Volume II: Categorical and Multivariate Methods. Springer-Verlag, New York.

Lara, J.J. - 1987. Los problemas del turismo en la Costa de Almería. Boletín del Instituto de Estudios Almerienses, 1: 255-268.

Margalef, R. - 1974. Ecología. Ediciones Omega, Barcelona.

Mas, J. - 1995. Actividades y procesos contaminantes del medio marino en el Mediterráneo Occidental. Situación actual. In: J. Guirado (coord.), La gestión de los espacios marinos en el Mediterráneo Occidental, pp. 119-148. Instituto de Estudios Almerienses, Almería.

Monaghan, P. - 1996. Relevance of the behaviour of seabirds to the conservation of marine environments. Oikos, 77: 227-237.

Monteiro, L.R., J.A. Ramos and R.W. Furness. - 1996. Past and present status and conservation of the seabirds breeding in the Azores Archipielago. Biol. Conserv., 78: 319-328.

Oliver, P. (ed.). - 1991. Bases técnicas para la regulación de la pesca de arrastre en el Mediterráneo. Inform. Téc. Inst. Esp. Oceanogr., 100: 3-34.

Oro, D. and X. Ruiz. - 1997. Exploitation of trawler discards by breeding seabirds in the north-western Mediterranean: differences between the Ebro Delta and the Balearic Islands areas. ICES J. Mar. Sci., 54: 695-707.

Paracuellos, M. and J.C. Nevado. - 1995. Nidificación de láridos en la provincia de Almería (SE Ibérico). Doñana, Acta Vertebrata, 22: 102-106.

Paracuellos, M., J.A. Oña, J.M. López Martos, J.J. Matamala, G. Salas and J.C. Nevado. - 1994. Caracterización de los humedales almerienses en función de su importancia provincial para las aves acuáticas. Oxyura, 7: 183-194.

Paterson, A.M. - 1990. Aves Marinas de Málaga y Mar de Alborán. Agencia de Medio Ambiente (Junta de Andalucía), Sevilla.

Paterson, A.M. - 1997. Las Aves Marinas de España y Portugal. Lynx Edicions, Barcelona.

Rodríguez, J. - 1982. Oceanografía del Mar Mediterráneo. Pirámide, Madrid.

Siegel, S. and N.J. Castellan Jr. - 1988. Nonparametric Statistics for Behavioral Sciences (2 ${ }^{\text {nd }}$ edn.). McGraw-Hill Book Company, New York.

Snow, D.W. and C.M. Perrins. - 1998. The Birds of the Western Paleartic. Concise Edition. Vol. 1, Non-Passerines. Oxford University Press, New York.

Sokal, R.R. and F.J. Rohlf. - 1994. Biometry. W. H. Freeman and Co., San Francisco.

Sultana, J. - 1993. Important Seabird Sites in the Mediterranean. Malta Ornithological Society, Valletta.

Tasker, M.L. and J.B. Reid. - 1997. Seabirds in the marine environment. Introduction. ICES J. Mar. Sci., 54: 505-506.

Thibault, J.C., R. Zotier, I. Guyot and V. Bretagnolle. - 1996. Recent trends in breeding marine birds of the Mediterranean Region with special reference to Corsica. Colonial Waterbirds, 19 (special publication 1): 31-40.

van Franeker, J.A. - 1994. A comparison of methods for counting seabirds at sea in the southern ocean. J. Field Ornithol., 65: 96-108.

Witt, H.-H., J. Crespo, E. de Juana and J.M. Varela. - 1981. Comparative feeding ecology of Audouin's gull Larus audouinii and the herring gull L. argentatus in the Mediterranean. Ibis, 123: 519-526. 
